\title{
Abundance of Ants on Chili and Corn Intercrop Planting Techniques
}

\author{
Haerul, Nurariaty Agus, A. Nasruddin, Ahdin Gassa
}

\begin{abstract}
These Ants play an important role as predators in agricultural habitats, including in controlling insect pests. The conducted research investigates the abundance of ants in several intercropping techniques on chili and corn. The intercropping techniques applied were: chili and corn intercropping using plastic mulch, corn and watermelon intercropping that did not use plastic mulch, chili and corn intercropping that did not use plastic mulch, and planting monoculture chili according to the treatment of farmers using plastic mulch and pesticides. The parameters observed in this study were the average population and fluctuations of ants in each intercropping technique. The results showed that the chili plants intercropped with corn, using plastic mulch or not, attracted more ants compared to the monoculture chili planting techniques according to farmers' habits. Observation of the ant population fluctuations captured using the pitfall trap and hand collecting method shows that the ant population is increasing with each observation
\end{abstract}

Keywords: Intercropping technique; ant; population;

\section{INTRODUCTION}

The presence of ants in agricultural habitats is influenced by the availability of food and the suitability of environmental conditions for nesting sites. Various literature says that ants generally act as predators that have an important role in agricultural habitats.

When it is time to overcome pest problems in chili plants, farmers generally apply pesticides. Whereas the use of pesticides has many negative impacts including: emergence of pest resistance, emergence of pest resurgence, second eruption of pests, pollution of soil and water, danger of poisoning to humans who come in direct contact with insecticides [15], and the presence of residues that can

Revised Manuscript Received on December 30, 2019.

* Correspondence Author

Haerul*, Agricultural Science Study Program, Graduate school student, Hasanuddin University,Makassars, Indonesia E-mail haerul_muhammad@pasca.unhas.ac.id

Nurariaty Agus, Lecturer, Faculty of Agriculture, Hasanuddin University,Makassar, Indonesia

A.Nasruddin, Lecturer, Faculty of Agriculture, Hasanuddin University,Makassar, Indonesia

Ahdin Gassa, Lecturer, Faculty of Agriculture, Hasanuddin University,Makassar, Indonesia

(C) The Authors. Published by Blue Eyes Intelligence Engineering and Sciences Publication (BEIESP). This is an open access article under the CC BY-NC-ND license (http://creativecommons.org/licenses/by-nc-nd/4.0/) fluctuation poison non-target organisms in soil [5].

Therefore more prudent pest management needs to be developed. At present, the concept of pest control is more likely to use an ecological approach. According to reference [10], an ecological approach strategy as a basis for biological pest control can minimize adverse risks by managing all components of the environment. Biological control utilizes controlling factors that already exist in nature, namely natural enemies of targeted organisms [7]. Reference [2] also has the same opinion, that an alternative control with an approach to maintain environmental protection for plants to avoid risks posed to humans and other organisms, bringing the idea of biological control by utilizing natural enemies is the right choice.

Ants are insects that have the potential to become natural enemies of insect pests, by acting as predators in rice fields [1]. Ants are the most common insects found on the surface of agricultural fields. Most ants are beneficial such as the Dolichoderus bituberculatus Mays which can attack caterpillars and several other pests such as Helopeltis spp. [9]. Predatory ants can significantly suppress the pest Cacopsylla pyricola (Hemiptera: Psyllidae) in pear plantations [12]. Also, the black ant, Dolichoderus thoracicus, found in cocoa plantations can also suppress Helopeltis spp [3].

The other role of ants is as an agent for spreading plant seeds derived from fruits that fall to the ground. The presence of a lipid substance (elaiosome) in the seed attracts ants to transport it to the nest. After the elaiosome is exhausted, the seed will be thrown out of the nest, but if the conditions are optimal, it may allow the seed to have the potential to germinate [6]. Also, ants become composting agents by bringing fungus and other organisms into their nests.

The presence of ants in an ecosystem can also be used as an indicator of changes in the ecosystem. If the habitat is disturbed, the performance of the ants is also disturbed. Reference [4] compares ant habitats on coffee plantations and grasslands found that coffee plantations (disturbed habitats) show a negative influence on the diversity of predator and omnivorous ants compared to grasslands which only exerts an influence on the abundance of predatory ants. It was also stated that biological pest control ability declined in disturbed habitats. Leading to the loss of diversity and changes in vegetation structures, as well as a shift in the abundance and composition of ants.

Research conducted revealed how the average ant population in chili and corn intercropping techniques, as well as ant population fluctuations along with the development of chili and corn plants. 


\section{MATERIALS AND METHODS}

Fieldwork was conducted from June 2018 to November 2018 in the Maros district, Indonesia. Chili, maize, and watermelon were planted on a $14.4 \mathrm{~m}$ x $5 \mathrm{~m}$ plot of land which was made into 12 beds of $1.2 \mathrm{~m} \mathrm{x} 5 \mathrm{~m}$ size (for each intercropping model). Chili was planted with a spacing of 50 $\mathrm{cm} \times 70 \mathrm{~cm}$ so that the population of each bed was 20 trees.

Corn (variety; sweet corn) was planted in five planting holes in each bed with a distance of $1 \mathrm{~m}$ between the rows of chili. Each planting hole was filled with two seeds of corn and four plants of watermelons were planted with one plant in each of the corners of the beds. The chili planting techniques applied were 1) chili and corn intercropping using plastic mulch, 2) chili, corn, and watermelon intercropping, not using plastic mulch, 3) chili and corn intercropping, not using plastic mulch, and 4) monoculture chili according to treatment farmers who use plastic mulch and pesticide spraying.

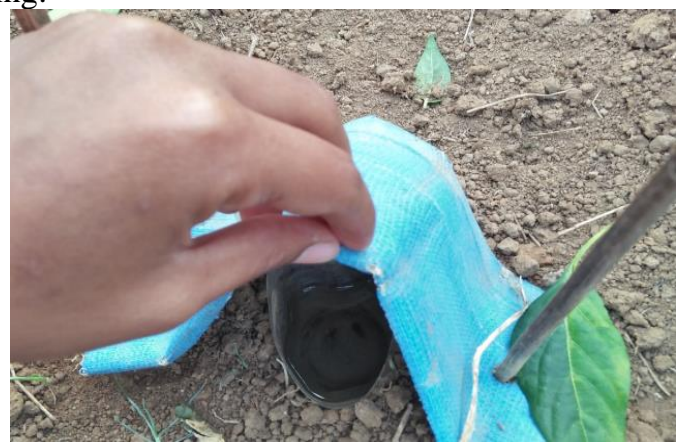

Fig.1. Installing the pitfall trap

Sampling for the ants was done every two weeks for the chili and corn treatments using two methods, namely: 1) the Pitfall trap method (figure 1) which uses a plastic cup measuring 10 $\mathrm{cm}$ high with a diameter of $7.5 \mathrm{~cm}$ planted into the ground and the brim of cup was leveled with the soil's surface. To prevent rainwater from entering the cups, a shade made from the skin of a banana trunk or the like covered the top of the plants and was then secured in place with bamboo. The cups were filled with a mixture of water with $1 \%$ detergent to $1 / 3$ part of the cup filled with soapy water and was placed for $1 \mathrm{x}$ 24 hours. The number of pitfall traps installed was nine units per cropping pattern. 2) The method of hand collecting (figure 2) was carried out by observing the ants that surround the corn and chili plants.

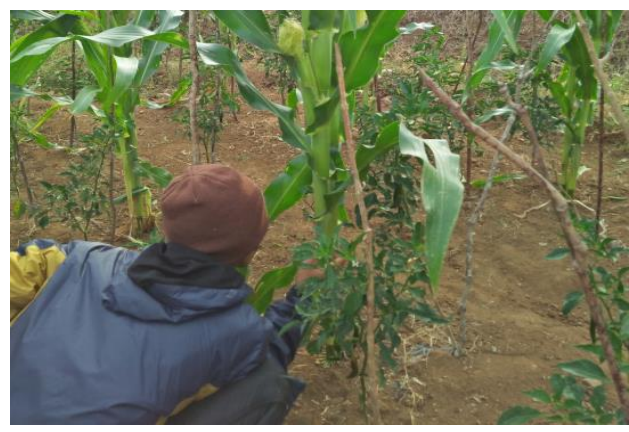

Fig.2. Direct Observation

The parameters observed in this study were the average ant population and its fluctuations in each intercropping technique.

\section{RESULTS AND DISCUSSIONS}

A. The average ant population in the intercropping of chili and corn

The results from the observations of the average ant population in each chili and corn intercropping techniques are shown in table 1.

Table 1. The average number of ants in each of the chili and corn intercropping techniques

\begin{tabular}{|l|c|c|c|}
\hline \multirow{2}{*}{$\begin{array}{c}\text { Intercropping } \\
\text { Techniques }\end{array}$} & \multicolumn{3}{|c|}{$\begin{array}{c}\text { Average number of ants caught } \\
\text { (units) }\end{array}$} \\
\cline { 2 - 4 } & $\begin{array}{c}\text { Hand } \\
\text { Collecting }\end{array}$ & $\begin{array}{c}\text { Pitfall } \\
\text { Trap }\end{array}$ & Total \\
\hline $\begin{array}{l}\text { Chili + Corn (with } \\
\text { plastic mulch) }\end{array}$ & 46 & 189,6 & 235,6 \\
\hline $\begin{array}{l}\text { Chili + Corn + } \\
\text { Watermelon } \\
\text { (without plastic } \\
\text { mulch) }\end{array}$ & 57 & 103,6 & 160,6 \\
\hline $\begin{array}{l}\text { Chili + Corn } \\
\text { (without plastic } \\
\text { mulch) }\end{array}$ & 218 & 112,25 & $330,25 *$ \\
\hline $\begin{array}{l}\text { Chili according to } \\
\text { farmers' treatment } \\
\text { (+ plastic mulch \& } \\
\text { pesticides) }\end{array}$ & 0 & 132,25 & 132,25 \\
\hline
\end{tabular}

${ }^{*}$ )The highest average number of ants

Reference [13] reveals that the total abundance of arthropods at the soil surface in the polyculture cultivated corn plantations was higher than that of monoculture cultivated corn. The research conducted revealed the same thing, where chili plants intercropped with corn using plastic mulch or not, were approached more by ants compared to monoculture chili planting techniques according to farmers' habits.

The role of mulch as an insect shelter as suggested by [14] was true. He revealed that mulching among plants plays an important role in maintaining the survival of arthropods in the ecosystem because it can be used as a shelter for natural enemies, especially at high temperatures. The planting technique that uses plastic mulch (such as Figure 3) shows that the average number of ants trapped in the pitfall trap was greater than without the use of plastic mulch.

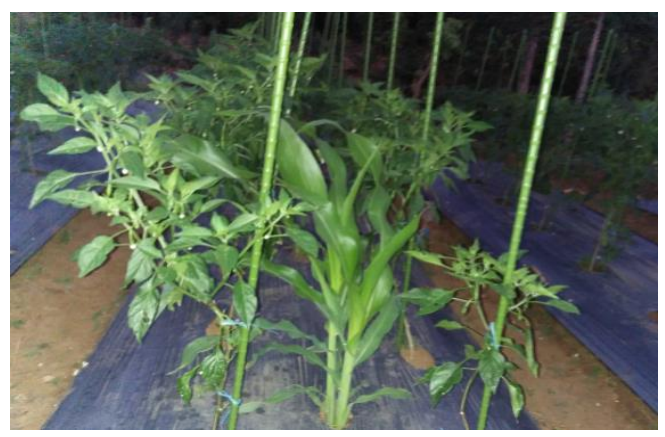

Fig. 3. Chili and corn intercropping using plastic mulch

In the research, chili plants that were planted and maintained according to the treatment of farmers seemed to repel ants from the chili plants. 
This can be ascertained due to the routine use of pesticides that were sprayed evenly throughout the plants. As is well known that the use of pesticides in addition to killing pests, will also kill non-target organisms, especially if not applied accordingly from the instructions by the pesticide's manufacturer. Herlinda et al. (2008) stated that the application of synthetic insecticides affects the diversity and abundance of predator arthropods that are active on the soil surface.

\section{B. Ant Population Fluctuations in the Chili and Corn Intercrop Techniques}

The observation of ant population fluctuations caught in the pitfall trap shows that plastic mulch plays a role in increasing the ant population around the plant. Results can be seen in Figure 4 below:

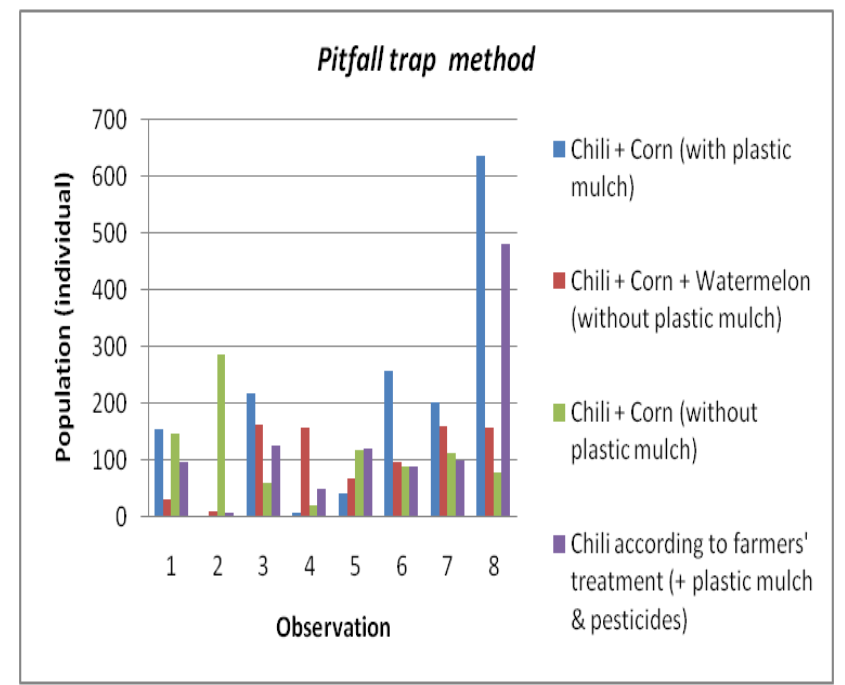

Fig. 4. Fluctuations of ant population caught by the pitfall trap every observation

The observation of the ant population, using the hand collection method, also increases following the development of the corn (can be seen in Figure 6). Corn plants seem to have a special attraction for ants, possibly caused by ant prey for the corn plant or ant interest in the morphological development of corn plants so that the ants come looking for food. Reference [13] states that the arthropods that dominate in maize plantations, both monoculture, and polyculture maize plants are arthropods that act as predators on the surface of the soil, one of which is ants.

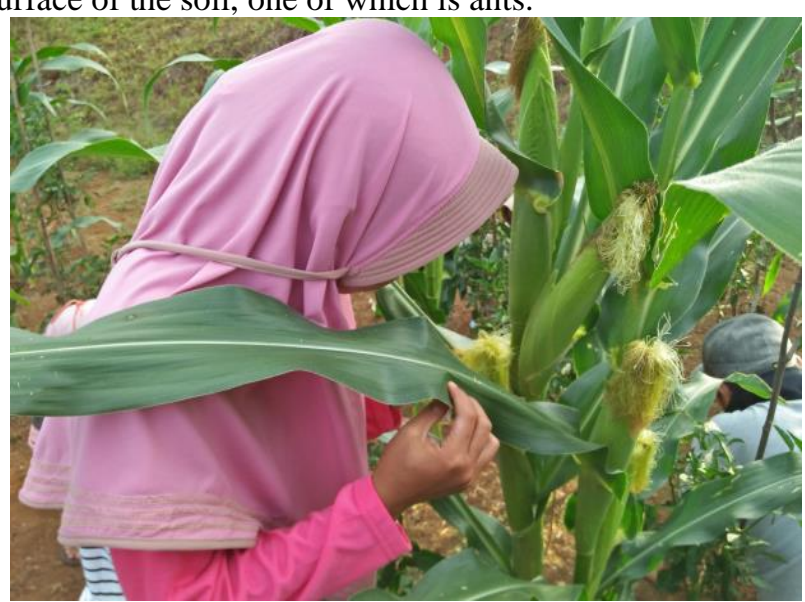

Fig. 5. Observation of the development of corn plants

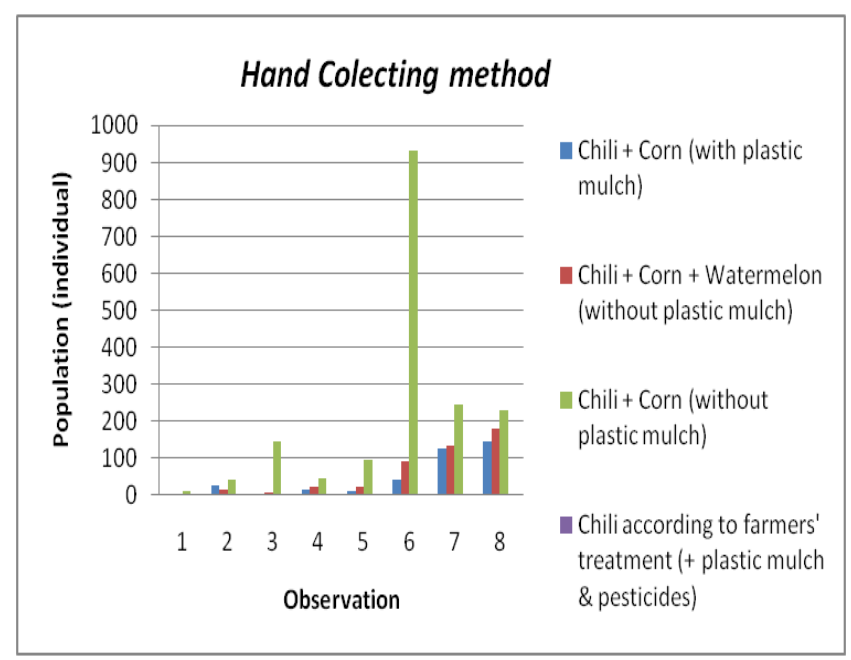

Fig. 6. Fluctuations of ant population captured using the hand collection method for each observation.

Figures 4 and 6 shows that the ant population tends to increase from each observation. It is likely related to the implementation of research conducted in the dry season. At the beginning of plant growth, the condition of the soil around the research area is still rather moist. As observations went on, the dry season was gradually intense causing the land around the study to become drier. The dry situation is thought to cause the population of captured ants to increase with each observation. Reference [11] stated that arthropod predators, such as ants, prefer relatively dry land.

\section{Conclusions}

The study revealed the cause of ant abundance and population fluctuations in some of the chili and corn intercropping techniques. The results showed that chili that was intercropped with corn attracted more ants, whether using plastic mulch or not, compared to monoculture chili planting techniques according to farmers' habits. The results show an increase in the ant population in line with the development of chili and corn plants.

\section{REFERENCES}

1. Adhi, S.L, Hadi, M \& Tarwotjo, U. 2017. Keanekaragaman dan Kelimpahan Semut sebagai Predator Hama Tanaman Padi di Lahan Sawah Organik dan Anorganik Kecamatan Karanganom Kabupaten Klaten. Bioma, Desember 2017 Vol. 19, No. 2, Hal. 125-135

2. Agus, N (2007). Konservasi Parasitoid Hemiptarsenus varicornis Grinault Sebagai Agens Pengendali Hayati Hama Liriomyza huidobrensis Blanchard di Pertanaman Kentang . Prosiding Seminar Ilmiah dan Pertemuan Tahunan PEI dan PFI XVIII Komda Sul-Sel, 2007

3. Anshary A, Pasaru , F. 2008. Teknik perbanyakan dan aplikasi predator dolichoderus thoracicus (smith) (hymenoptera: Formicidae) untuk pengendalian penggerek buah kakao (conopomorpha cramerella (snellen) di perkebunan rakyat. Journal Agroland. 15(4): 278-287.

4. Dias NDS, Zanetti R, Santos MS, Peñaflor MFGV, Broglio SMF, Delabie5f JHC. 2012. The impact of coffee and pasture agriculture on predatory and omnivorous leaf-litter ants. Journal of Insect Science. 13(29).

5. Djunaedy, A. (2009). Biopestisida sebagai pengendali organisme pengganggu tanaman (OPT) yang ramah lingkungan. Embryo, 6(1), 88-95.

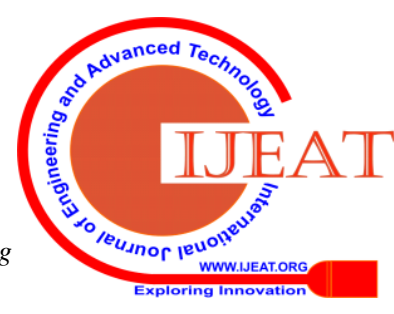




\section{Abundance of Ants on Chili and Corn Intercrop Planting Techniques}

6. Gammans N, Bullock JM, Schönrogge K. 2005. Ant benefits in a seed dispersal mutualism. Oecologia. 146(1): 43-49.

7. Herlinda, S. (2008). Pemanfaatan Musuh Alami dalam Pengendalian Hama Tanaman. Pidato Pengukuhan Sebagai Guru Besar Tetap Ilmu Hama dan Penyakit Tumbuhan pada Fakultas Pertanian Universitas Sriwijaya. Sabtu, 19 Januari 2008. Hal 1.

8. Herlinda S, Waluyo, Estuningsih SP, Irsan C. 2008. Perbandingan keanekaragaman spesies dan kelimpahan artropoda predator penghuni tanah di sawah lebak yang diaplikasi dan tanpa aplikasi insektisida. J Entomol Indonesia 5(2): 96-107.

9. Hutauruk CH. 1988. Penggunaan semut hitam Dolichoderus bituberculatus Mays (Hymenoptera: Formicidae) untuk mengendalikan hama pengisap buah Helopeltis antonii Signoret (Hemiptera: Miridae) pada kakao Linduk (Theobroma cacao L.). Prosiding Komunikasi Teknis Kakao 1988. Balai Penelitian Perkebunan Jember. hlm. 188-211.

10. Kartohardjono, A. 2011. Penggunaan Musuh Alami sebagai Komponen Pengendalian Hama Padi Berbasis Ekologi. Pengembangan Inovasi Pertanian. 4(1): 29- 46.

11. Kalshoven LGE. 1981. The Pests of Crops in Indonesia (Revised and Translated by van der Laan PA). PT Ichtiar Baru-Van Hoeve. Jakarta: 701 p.

12. Paulson GS, Akre RD. 1992. Evaluating the effectiveness of ants as biological control agents of pear phyla (homoptera: Psyllidae). Journal of Economic Entomological. 85(1): 70-7

13. Tamrin, Hidayat P, Rauf A, Sartiami D. 2004. Artropoda permukaan tanah pada pertanaman jagung. Bogor: Kongres PEI VI dan Simposium Nasional Entomologi. Cipayung, 5-7 Maret 2003.

14. Taulu, L.A. 2001. Kompleks Arthropoda Predator Penghuni Tajuk dan Peranannya dengan Perhatian Utama pada Paederus fuscipes (Curt.) (Coleoptera:Staphylinidae). Disertasi. Program Pascasarjana Institut Pertanian Bogor. 40 hal.

15. Untung K. (1993). Pengantar Pengelolaan Hama Terpadu. Gadjah Mada University Press. Yogyakarta. 273 hal.

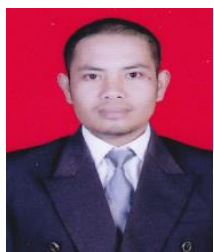

\section{AUTHORS PROFILE}

Haerul, a student in the doctoral program at Hasanuddin University, entered the Agriculture Science study program in 2016. Completing the master's program also at Hasanuddin University in the study program of pest and plant diseases in 2014. The focus of research conducted at present is the relationship between insects and plants.

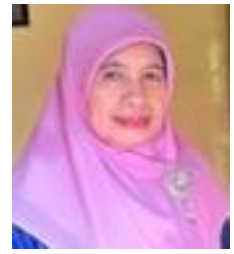

Prof. Dr. Nurariaty Agus, MS Is a professor at the Faculty of Agriculture, Hasanuddin University. Her area of expertise is biological control. Her experience in his field is not in doubt. This can be seen from the focus of the research he has done. She has guided dozens of doctoral, master's and undergraduate students for decades.

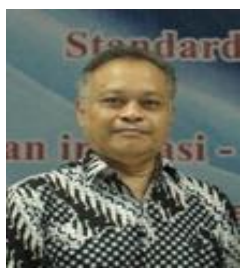

Dr.Ir. Andi Nasruddin, MSc is a lecturer at the Faculty of Agriculture, Hasanuddin University. His area of expertise is the relationship of insects and plant diseases. He completed his master's program at Michigan State University in the United States and his doctorate at the University of Minnesota in the United States. His articles on pests and plant diseases have been widely published in leading journals, both national and international

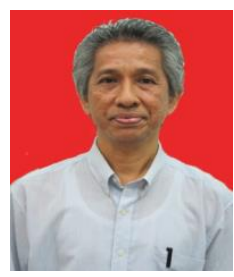

Dr. Ir. Ahdin Gassa, MS is a lecturer at the Faculty of Agriculture, Hasanuddin University. His areas of expertise are pest and plant diseases. He completed his master's program at Kyoto University-Japan and his doctorate also at Kyoto University-Japan. His papers on pests and plant diseases have been widely published in reputable journals, both national and international 